\title{
New record of a freshwater crab Phricotelphusa callianira (De Man, 1887) (Decapoda: Brachyura: Gecarcinucidae) from Thailand
}

\author{
Vachira Lheknim ${ }^{1}$ \& Pimonpan Leelawathanagoon ${ }^{2}$ \\ 1,2 Department of Biology, Prince of Songkla University, PO Box 3 Ko Hong, Songkhla 90112, Thailand \\ Email: ${ }^{1}$ vachira.I@psu.ac.th
}

Date of publication (online): 26 September 2009 Date of publication (print): 26 September 2009 ISSN 0974-7907 (online) | 0974-7893 (print)

Editor: Stephan Gollasch

\section{Manuscript details:}

Ms \# 01901

Received 05 December 2007

Final received 08 September 2009

Finally accepted 11 September 2009

Citation: Lheknim, V. \& P. Leelawathanagoon (2009). A new record freshwater crab Phricotelphusa callianira (De Man, 1887) (Decapoda: Brachyura: Gecarcinucidae) from Thailand. Journal of Threatened Taxa 1(9): 461 465

Copyright: () Vachira Lheknim \& Pimonpan Leelawathanagoon 2009. Creative Commons Attribution 3.0 Unported License. JoTT allows unrestricted use of this article in any medium for nonprofit purposes, reproduction and distribution by providing adequate credit to the authors and the source of publication.

Author Details: see end of this article.

Author Contribution: VL is involved in specimen collection, identification and preparing descriptions in the present study. PL is responsible for identification and preparing descriptions in the present study.

Acknowledgement: This is the Prince of Songkla University Zoological Collection Contribution No. 5. Logistic support for transportation and working at Ko Tachai and Ko Bon from Naval Specia Warfare Unit, Naval Fleet Command, the Royal Thai Navy and Plant Genetic Conservation Project under the Royal Initiative of Her Royal Highness Princess Maha Chakri Sirindhorn are greatly appreciated by VL. We would like to thank Prof. P.K.L. Ng and Dr. Darren Yeo of Raffles Museum of Biodiversity Research (ZRC), Department of Biological Sciences, National University of Singapore for suggestions and help in examining our specimens from Thailand. Dr. Harold K. Voris and Jeniffer Mui of the Field Museum of Natura History (FMNH) kindly read and correcting the early draft of this manuscript. Three anonymous reviewers who greatly improved this manuscript are also acknowledged.
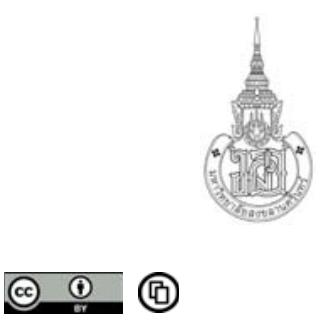

OPEN ACCESS | FREE DOWNLOAD
Abstract: An expedition by scientists participating in a Plant Genetic Conservation Project under the Royal Initiative of Her Royal Highness Princess Maha Chakri Sirindhorn to Tachai Island, off the coast of Changwat Phangnga, Andaman Sea, southern Thailand in April 1999, revealed a new record of the freshwater crab Phricotelphusa callianira (De Man 1887). The new distribution data is considered indicative of a lack of freshwater biota surveys in the area studied, and emphasizes the need for further biogeographical studies.

Keywords: Freshwater crab, Mergui Archipelago, Phricotelphusa callianira, plant genetic conservation project, southern Thailand.

\section{INTRODUCTION}

Several joint scientific expeditions of botanists, zoologists and marine biologists participating in the Plant Genetic Conservation Project under the Royal Initiative of Her Royal Highness Princess Maha Chakri Sirindhorn, supported by the Royal Thai Navy, explored the flora and fauna associated with the islands in Thailand's jurisdiction between 1999 and 2008. One of the expeditions was organized between 2 \& 11 April 1999 to visit the lesser known islands, Ko Tachai (Tachai Island) and Ko Bon (Bon Island) in the Andaman Sea. These islands are under the jurisdiction of the Royal Thai Navy. The purpose of the expedition was to make preliminary studies of the fauna and flora of the islands and surrounding areas.

\section{Materials and Methods}

Ko Tachai is a small isolated island in the Andaman Sea, about $1.25 \mathrm{~km}^{2}$ in area, lying on the edge of the continental shelf approximately $70 \mathrm{~km}$ from Phang-nga Province off the west coast of the Thai peninsula, approximately $40 \mathrm{~km}$ south of the $\mathrm{Mu}$ Ko Surin (Surin Islands) and $40 \mathrm{~km}$ north of the Mu Ko Similan (Similan Islands). It is located south of the Myanmar border at $9^{\circ} 03.50^{\prime}-9^{\circ} 05.00^{\prime} \mathrm{N} \& 97^{\circ} 48.50^{\prime}-97^{\circ} 49.25^{\prime} \mathrm{E}$ (Fig. 1). The surrounding waters are relatively shallow, but approximately $150-800 \mathrm{~m}$ from the shoreline the water exceeds $30 \mathrm{~m}$ in depth. The terrestrial part of the island is covered with tropical rain forest over a small hill approximately $100 \mathrm{~m}$ in height, and there is a thin zone of beach forest in the sheltered area northeast of the island. There is a small creek near the beach forest, which flows during the rainy season. The mature primary forest extends as far as $20-50 \mathrm{~m}$ from the shoreline. The substratum is primarily granite and soil covered with dry leaves. There is no evidence of human settlement on the island. Very little was previously known about the fauna of this relatively unexplored island, probably due to the remote location.

During the expedition, the first author visited the small dry freshwater creek on Ko Tachai to search for terrestrial crab specimens, Gecarcoidea lalandii (Gecarcinidae: Brachyura). He also encountered some small colorful brachyuran crabs underneath rocks among leaf litter and mosses, approximately $100 \mathrm{~m}$ from the shoreline to the upstream and at an elevation of approximately 3-5 m above the spring high water mark. Crabs were haphazardly collected, fixed in 10\% neutral formalin for two months and transferred to $70 \%$ ethanol. Specimens were examined and mainly deposited at Prince of Songkla University Zoological Collection (PSUZC), Thailand. Morphological terms used basically follow those used by $\mathrm{Ng}$ (1988a).

The authors tentatively identified the collected specimens as belonging to the genus Phricotelphusa of the family Gecarcinucidae Rathbun, 1904. So far, five species of the genus Phricotelphusa are known in Thailand (Naiyanetr, 1998), viz. P. aedes (Kemp 1923), P. limula (Hilgendorf 1882), P. ranongi Naiyanetr, 1982, P. sirindhorn Naiyanetr, 1989, and $P$. deharvengi $\mathrm{Ng}, 1988 \mathrm{~b}$, none of which correspond with the specimens collected 
from Ko Tachai. During March 2001, the authors visited the Zoological Reference Collection, Raffles Museum of Biodiversity Research, Department of Biological Sciences, National University of Singapore (ZRC) and met Dr. Darren Yeo, who had previously studied and examined various type specimens of freshwater crabs from Indo-China. He confirmed that the specimens collected are Phricotelphusa callianira (De Man 1887).

\section{Results}

Phricotelphusa callianira (De Man 1887), is a poorly-known freshwater crab previously documented only from the Mergui Archipelago, Gulf of Bengal. Originally this species was described from eight males and seven females obtained in the mangrove swamps of Kesseriang and Sullivan Islands in southern Myanmar (De Man 1887) (Fig. 1). As far as we know, this species has only been recorded from the type locality (De Man 1887; Bott 1970). P. callianira is one of the two species of Phricotelphusa (the other is P. carinifera) which have been found to inhabit relatively isolated islands. Other known species of the genus are found in the mainland $(\mathrm{Ng}$ 1988a).

Thus specimens from Ko Tachai, which is approximately $350 \mathrm{~km}$ south of the type locality "Sullivan Islands", have become the first record of P. callianira (De Man 1887) in Thailand. The presence of the species is unexpected since the two islands are far apart with a marine environment barrier. Previously, the macrofauna from the mangrove forest and adjacent biotopes from Ko Surin Nua (Surin Nua Island), approximately $45 \mathrm{~km}$ north of Ko Tachai, were surveyed and only hermit crabs (family Paguridae) and grapsid crabs were recorded (Frith 1977). Land crabs from Mu Ko Similan were also studied and only decapod crustaceans belonging to the families Coenobitidae, Ocypodidae, Grapsidae and Gecarcinidae were recorded (Frith \& Alexander 1978). Pretzmann (1984) collected and studied crabs from the freshwater part of the Andaman Islands, and he only found members of the family Grapsidae in the rivers and freshwater creeks there.

\section{Gecarcinucidae Rathbun, 1904}

\section{Phricotelphusa callianira (De Man, 1887)}

Thelphusa callianira De Man, 1887: 96-100, Pl.6 figs 1-3

Potamon (Potamon) callianira (De Man, 1887) - Rathbun, 1904: 239 (list), 250 (key), 303 (locality).

Phricotelphusa callianira (De Man, 1887) - Alcock, 1910: 101102 (with key)

Phricotelphusa callianira callianira (De Man, 1887) - Bott, 1970: 52-53(with key), Pl.6 figs.66-68, Pl.27 fig. 30 7 (key)

Phricotelphusa callianira (De Man, 1887)- Chuensri, 1974: (list).

Material Examined: 6.iv.1999, 8 males (4.9-17.0mm CW), 3 females (7.4-8.9mm CW), 9 $04.50^{\prime} \mathrm{N} \& 97^{\circ} 49.00^{\prime} \mathrm{E}$, alt $3-5 \mathrm{~m}$., Ko Tachai, off Amphoe Khura Buri, Changwat Phangnga, coll. V. Lheknim, PSUZC-19990406-01.01.

Comparative materials: Phricotelphusa ranongi Naiyanetr, 1982: PSUZC-19980921-01.13, 18 males (6.5x7.7-13.4x16.7), 12 females (8.3-15.0), $9^{\circ} 43.86^{\prime} \mathrm{N} \& 98^{\circ} 41.39^{\prime} \mathrm{E}$, alt 200m., Haew Ho Lom Waterfall (Klong Lak Rek), watershed area of Lang Suan River, Amphoe Phato, Chumphon, coll. V. Lheknim \& P. Leelawathanagoon, 21.ix.1998; PSUZC-20010524-04.10, 1 juv (6.0x7.3), $10^{\circ} 30.20^{\prime} \mathrm{N} \& 98^{\circ} 53.15^{\prime} \mathrm{E}$, alt 80m., Chum Sang Waterfall, Ban Nam Tok, Amphoe Kra Buri, Changwat Ranong, coll. V. Lheknim \& P. Leelawathanagoon, 24.v.2001.

\section{Description}

Carapace is relatively low, slightly broader than long (Image 1a). Anterolateral margin slightly convex. Posterolateral margins entire, gently concave, converging posteriorly. Frontal margin nearly straight, almost at right angles with internal angle of orbits, slightly more than a third of carapace width (Image $1 \mathrm{~b}$ ). Frontal region deflexed vertically downwards, finely granulated. Exorbital angle well developed, relatively triangular broad. Dorsal carapace surface depressed, somewhat flattened. Epigastric crest slightly arcuated, relatively low, sharp, transversely rugose anteriorly (Image 1c). Postorbital crest sharp, nearly straight, not reaching epibranchial teeth. Postorbital crest behind and distinctly separated from epigastric crest by a notch, approximately $1 / 3$ length of epigastric crest. Epibranchial teeth acute, prominent. Short oblique rugae present between postorbital crests and epibranchial teeth. Carapace regions poorly defined, only semicircular H-shaped gastric groove distinct, which separates gastric region from cardiac region. Branchial regions relatively smooth, faintly demarcated from gastric region by shallow cervical groove anteriorly.

Mouthparts: Third maxilliped exopod extends beyond edge of merus, flagellum absent; merus with very faint medial ischial sulcus (Fig. 2a). Posterior margin of epistome with broadly triangular median lobe.

Abdomen: Abdominal segments 1-5 gradually narrowing from anterior to posterior margins; segment 6 nearly rectangular, slightly longer than broad; lateral margins nearly straight (Image 1d and Fig. 2e). Telson slightly longer than basal width, tip round; lateral margins slightly concave at $1 / 4$ of length, then gradually converging posteriorly.

Chelipeds unequal: Outer and upper surfaces of merus and carpus rugose, inner margins are granular. Carpus with a small inner subdistal spine. Palm inflated, longer than high. Fingers of large chela gaping, shorter than palm, tips hooked, crossing one another when closed, both toothed along cutting edges (Fig. $2 \mathrm{~d}$ ). The teeth of movable finger proximally large, distally small, those on fixed finger small. Fixed finger with a shallow longitudinal groove on outer surface. Fingers of small chela rather slender, straight, not gaping when closed, but crossing at tips, cutting edges with small teeth.

Ambulatory legs: Legs relatively long, slender. Dorsal and ventral margins of meri of second to fourth legs convex, those on first one almost straight. Dactylus elongate, slender. Upper margin of merus weakly serrated, subdistal spine weak.

G1: relatively stout; not twisted, terminal joint subconical, straight, relatively short about 0.3 times length of subterminal joint, tip truncate, slightly bent outwards; subterminal joint faintly sinuous (Fig. 2b \& c).

Color: Large adult specimens with deep brown carapace and orange-yellowish chelipeds with brown tips. Ventral surfaces dirty white.

Sizes: The largest carapace width in our collection was 


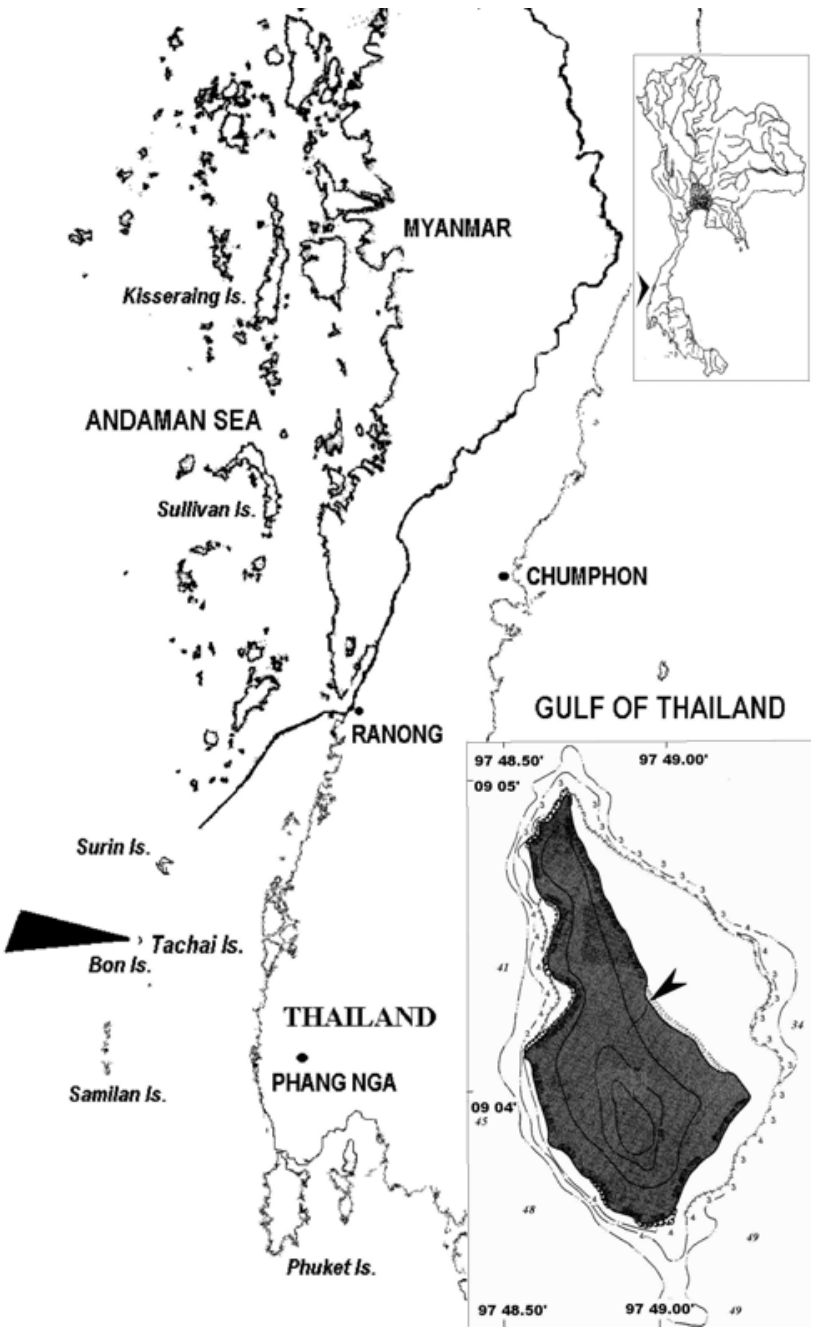

Figure 1. The part of the Mergui Archipelago adjacent to the western coast of the Thai Peninsula showing location of the type specimens, Kesseriang and Sullivan Islands; and current recorded specimens from Ko Tachai (Tachai Island), southern Thailand (indicated by black arrow). Inset: Ko Tachai (Tachai Island), with arrow indicating collecting area of Phricotelphusa callianira (De Man, 1887), in this report.

Table 1. Selected morphometric measurement (in $\mathrm{mm}$ ) of the largest male specimen of Phricotelphusa callianira (De Man 1887) from Ko Tachai (Tachai Island), off Amphoe Khura Buri, Changwat Phangnga south Thailand

\begin{tabular}{lc}
\hline Morphometric characters & Measurement $(\mathbf{m m})$ \\
\hline Length of carapace & 13.7 \\
Width of carapace & 17.5 \\
Width of frontal margin & 6.1 \\
Length of large hand & 18.3 \\
Height of large hand & 8.8 \\
Length of large palm & 11.6 \\
\hline
\end{tabular}

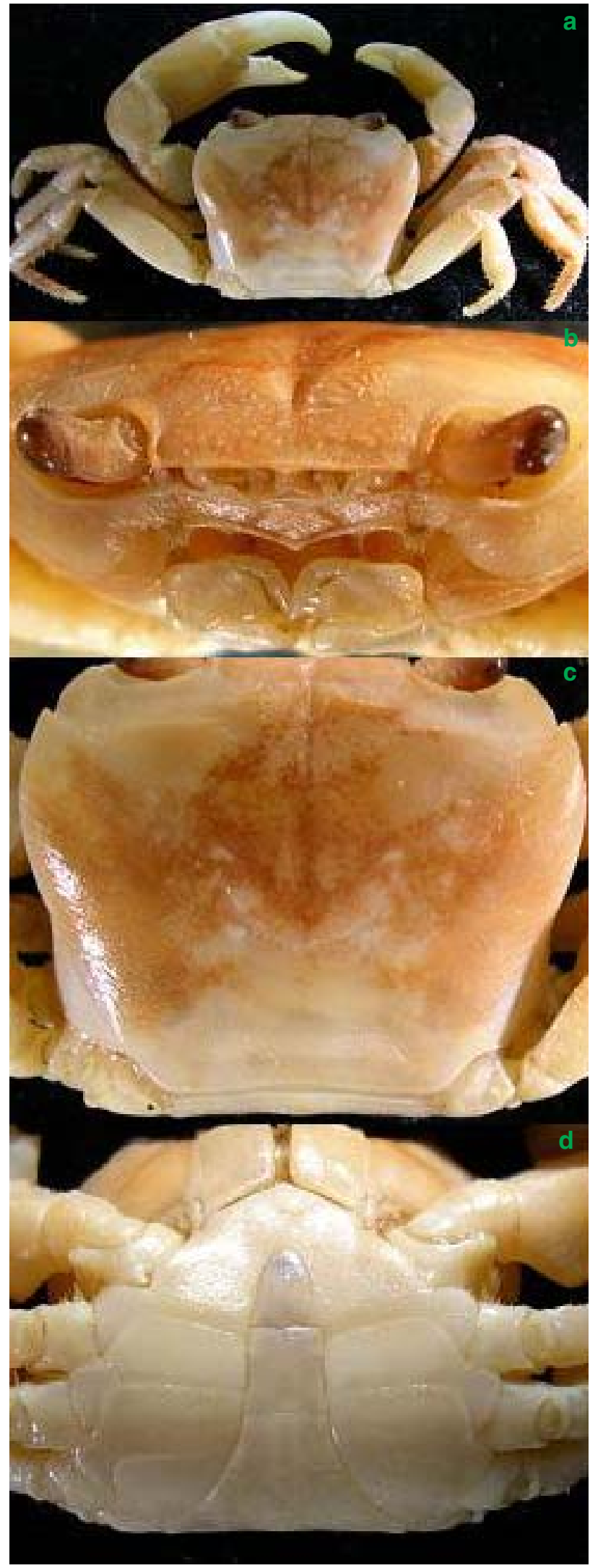

Image 1. Phricotelphusa callianira (De Man, 1887), PSUZC19990406-01.01A (Male:13.7x17.5mm), preserved in 70\% Ethanol, from Ko Tachai (Tachai Island), off Amphoe Khura Buri, Changwat Phangnga, Collected by V. Lheknim, 6 April 1999.

a - dorsal view; b - frontal view; c - dorsal surface of carapace; $\mathrm{d}$ - ventral view. 

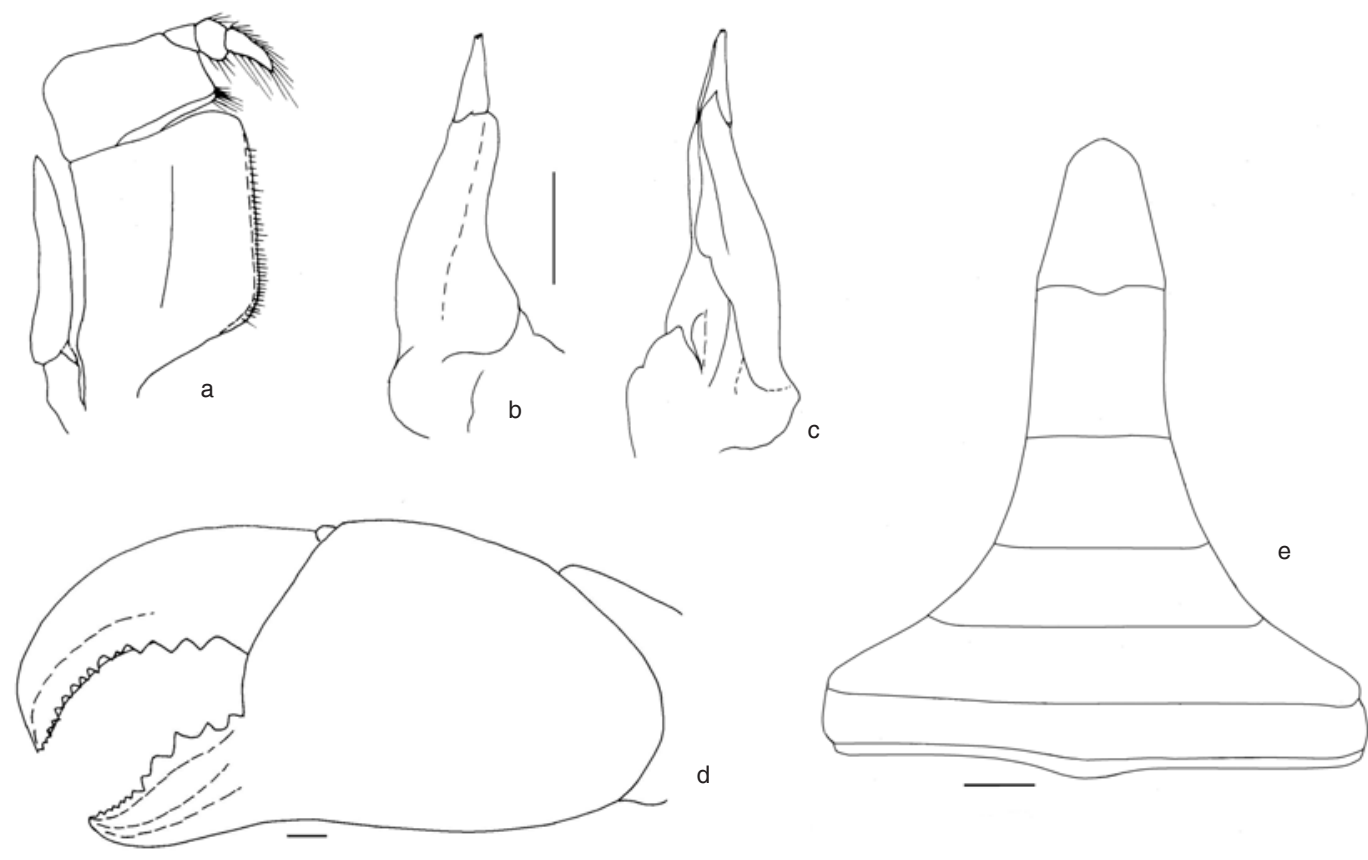

Figure 2. Phricotelphusa callianira (De Man, 1887), PSUZC-19990406-01.01A (Male:13.7x17.5mm) from Ko Tachai (Tachai Island), off Amphoe Khura Buri, Changwat Phangnga, Collected by V. Lheknim, 6.vi.1999.

a - right third maxilliped; b - ventral view of right G1 (setae omitted); c - dorsal view of right G1 (setae omitted); $d$ - outer surface of left chela; e - abdomen. Scales: $1.0 \mathrm{~mm}$.

$17.5 \mathrm{~mm}$. compared to the type specimens which measure $14.0-$ $16.0 \mathrm{~mm}$ (De Man 1887). Measurements (in millimetres) of the largest male specimen are given in Table 1.

Habitat: The present specimens were collected under rocks covered with dry leaves from a seasonal creek in the beach forest adjacent to an intertidal sandy beach. Observations indicate that they prefer areas near moist soil but are very active on land. This is contrary to the semiterrestrial to fully freshwater aquatic habits of other Phricothelphusa spp. elsewhere $(\mathrm{Ng} 1988 \mathrm{a})$.

\section{Discussion}

Our specimens of Phricotelphusa callianira from Ko Tachai agree well with the description and figures given by De Man (1887). In addition, Dr. Darren Yeo of Zoological Reference Collection (ZRC), Raffles Museum of Biodiversity Research, National University of Singapore presented his unpublished photographs and drawings of the types of the species including the structure of the gonopods, now in Instituut voor Systematiek en Populatiebiologie [formerly Zoological Museum, University of Amsterdam, Amsterdam, the Netherlands (ZMA)] and Nationaal Natuurhistorische Museum [formerly Rijksmuseum van Natuurlijke Historie (RMNH)], Leiden, the Netherlands. The morphology and dorsal ridge patterns on the carapace of our specimens (Image 1), match the drawing of $P$. callianira in De Man (1887, pl 6, Figs. 1 and 2). The G1 of the present Thai material (Fig. 3) also agrees well with the figure given in Bott (1970, Pl. 27, Fig. 30). As such, we believe our specimens are conspecific. $P$. callianira appears to be most similar to $P$. ranongi Naiyanetr 1982, but can be distinguished by the following characters: G1 subterminal joint faintly sinuous compared to almost straight in P. ranongi $(\mathrm{Ng} \&$ Naiyanetr, 1993) (see also Fig. 59B \& C in Bott, 1970), dactylus and pollex of small and large chela are relatively thicker and stouter compared to the relatively slender fingers in $P$. ranongi, the small chela of $P$. callianira has a movable finger which is shorter than the palm whereas this finger is longer than the palm in $P$. ranong $i$, and the 6 th abdominal segment of $P$. callianira is slightly rectangular (lateral margins longer than anterior and posterior margins) but is trapezoidal in P. ranongi.

It is interesting to note that of the 11 recognized species of Phricotelphusa known, P. callianira and P. carinifera were known to be insular species, occurring on the edge of the Mergui Archipelago, while the rest of the species from Thailand and Malaysia are more continental species. Recently, Voris (2000) reconstructed sea-level changes in the Southeast Asia shoreline by using present-day bathymetric depth contours and indicated this part of the Mergui Archipelago has been disconnected from the rest of the archipelago some 7,500yr BP. Some questions remain. First, how did this freshwater crab species end up being distributed only on the islands of the archipelago? Second, how much genetic variation exists between populations morphologically identified as P. callianira along the islands chain at the rim of the Mergui Archipelago. Finally, what adaptations enable the crabs to live on such small islands with clear seasonality in the climate? More data on the activity of $P$. callianira during the dry period, and their adaptation to survive and reproduce on such a small isolated island would be interesting (Hartnoll 1988).

Due to limited information on the population status of Phricotelphusa callianira in the Myanmar jurisdiction and only one presently known locality in Thai's jurisdiction at Ko Tachai, conservation measures for this species at this locality are clearly necessary 


\section{REFERENCES}

Alcock, A. (1910). Catalogue of the Indian Decapod Crustacea in the Indian Museum, Part I: Brachyura, Fasc. 2: The Indian Freshwater Crabs-Potamonidae. Indian Museum, Calcutta, 135pp.

Bott, R. (1970). Die Süsswasserkrabben von Europa, Asien, Australien und ihre Stammesgeschichte. Eine Revision der Potamoidea und Parathelphusoidea (Crustacea, Decapoda). Abhandlungen der Senckenbergischen Naturforschenden Gesellschaft in Frankfurt 526: 1338.

Chuensri, C. (1974). Key to Freshwater Crabs (excluded Pseudothelphusidae and Potamocarcinidae). College of Fisheries, Kasetsart University, 52pp.

De Man, J.G. (1887). Report on the Podophthalmous Crustacea of the Mergui Archipelago, collected for the Trustees of the Indian Museum, Calcutta- Part 2. Journal of the Linnean Society of London Zoology 22(137): 65-128.

Frith, D.W. (1977). A preliminary list of macrofauna from a mangrove forest and adjacent biotopes at Surin Island, western Peninsula Thailand. Phuket Marine Biological Center, Phuket, Thailand Research Bulletin No. 17, 1-14.

Frith, D.W. \& H.G.L. Alexander (1978). A preliminary list of land crabs (Crustacea: Decapoda) from Koh Similan, Andaman Sea, including eight species new to Thailand. Phuket Marine Biological Center, Phuket, Thailand Research Bulletin No. 24. 1-6.

Hartnoll, R.G. (1988). Evolution, systematics, and geographical distribution, pp.6.54. In: W.W. Burggren and B.R. McMahon (eds.). Biology of Land Crabs. Cambridge University Press, Cambridge, $497 \mathrm{pp}$.

Hilgendorf, F. (1882). Einige carcinologische Mittheilungen. S.B. Gesellschaft Naturforschender Freunde, Berlin 1882:22-25

Kemp, S. (1923). On a collection of river crabs from Siam and Annam. Journal of Natural History Society, Siam 6: 1-42.

Naiyanetr, P. (1982). Three new species of freshwater crabs of Thailand. Abstract of the Twentieth Annual Conference on Fisheries Section, Kasetsart University, Bangkok, Thailand, 2 pp.

Naiyanetr, P. (1989). Phricotelphusa sirindhorn n.sp., a new freshwater crab from Thailand (Decapoda: Brachyura: Gecarcinucidae). Crustaceana 56: 225-229+1pl.

Naiyanetr, P. (1998). Checklist of Crustacean Fauna in Thailand. Office of Environmental Policy and Planning, Bangkok, Thailand, 105pp.

Ng, P.K.L. (1988a). The Freshwater Crabs of Peninsular Malaysia and Singapore. The Department of Zoology, National University of Singapore, Shinglee Press, Singapore, 156pp.

Ng, P.K.L. (1988b). Freshwater crabs (Crustacea, Decapoda, Brachyura) from Thailand and Sulawesi. In: Expéditions de 12 APS [Association Pyrénéene de Spéléologie] en Asie-du Sud-est travaux scientifiques, Toulouse, France, 1 :23-27, figs.1-3.

Ng, P.K.L. \& P. Naiyanetr (1993). New and recently described freshwater crabs (Crustacea: Decapoda: Brachyura: Potamidae, Gecarcinucidae and Parathelphusidae) from Thailand. Zoologische Verhandelingen, Leiden 284: 1-117.

Pretzmann, G. (1984). Results of the Austrian-Indian Hydrobiological Mission 1976 to the Andaman Islands, Part III: Brachyura from the Andaman Islands. Annalen des Naturhistorischen Museums in Wien 86B: 141-144.

Rathbun, M.J. (1904). Les Crabes D'eau Douce (Potamonidae). Nouvelles Archives Du Muséum D' Histoire Naturelle, Paris 4(6): 225-312.

Voris, H.K. (2000). Maps of Pleistocene sea levels in Southeast Asia: shoreline, river systems and time durations. Journal of Biogeography 27: 1153-1167.
Author Details: VACHIRA LHEKNIM is an Assistant Professor in the Department of Biology and Chief Curator of Prince of Songkla University Zoological Collection (PSUZC) at Prince of Songkla University. He is keenly interested in marine and freshwater biology and local fauna. Currently, he is engaged in ichthyological surveys of freshwater fishes in all river basins of southern Thailand.

Pimonpan Leelawathanagoon is an Assistant Professor in the Department of Biology and Curator of Crustacean Section of Prince of Songkla University Zoological Collection (PSUZC) at Prince of Songkla University. She has long experience in study of both marine and freshwater decapod crustaceans in southern Thailand. Currently, she is investigating the diversity of freshwater crabs of southern Thailand. 